\title{
Tolerance - a Culturally Dependent Concept?
}

Trond Jørgensen

Independent researcher

E-Mail: trondbox@gmail.com

\author{
Keywords: \\ confucianism \\ culture \\ human rights \\ Japan \\ liberalism \\ moral philosophy \\ tolerance
}




\begin{abstract}
This article presents research on Japanese interpretations of the first article of the Universal Declaration of Human Rights as a point of departure for discussing how the Japanese cultural contexts present an alternative understanding of tolerance to the Western liberal.

According to Rainer Forst, tolerance is a normatively dependent concept (Forst 2010). This implies that the specific cultural values or the 'normative context' and environment become relevant. Since the praxis of tolerance always takes place in a specific cultural and moral environment, the cultural context influences how tolerance is carried out in practice as well as the norms defining its limits.

Japanese informants held that cultural norms and values in Japan differ somewhat from those in the West. They perceived the human rights discourse as culturally dependent and culturally marked and clearly considered the first article of the Universal Declaration of Human Rights to be a product of Western thought. It states that 'All human beings are born free and equal in dignity and rights. They are endowed with reason and conscience and should act towards one another in the spirit of brotherhood' (United Nations 1948). While the role of tolerance in Western political philosophy seems to be attached to liberal values of autonomy and freedom, the Confucian-influenced environment in Japan places more emphasis on inter-dependency, cultivation, and learning social rules and proper-placeoccupation as bases for moral conduct and deserving of respect. According to the Japanese informants, people are not 'born with rights' or 'born free and equal'. Maintaining harmony, consensus, and proper behaviour according to relationships and hierarchy creates a different kind of setting for tolerance. The inter-dependent perspectives of Japanese culture may restrain freedom and can thus be expected to limit toleration of divergent views or behaviour. The culture-specific perception of human nature with an 'inter-dependent construal of self', counts as a context for tolerance. Also, it could be argued that Japanese religion is less doctrinal and absolute, and particularistic morality prevails. In the Japanese setting, the coexistence of competing truth systems seems to be more easily tolerated. This may broaden the room for tolerance. The cultural values defining 'the good' vary, implying that culture counts when the limits for tolerance are drawn. What is valued is culturally dependent, thus directing what is tolerated.
\end{abstract}




\section{Introduction}

Tolerance is an issue in all societies, cultures and political systems. What should be tolerated and what should not is at stake all over the world. According to Rainer Forst, tolerance is a normatively dependent concept (Forst 2010). In that way tolerance is neutral in itself and in need of a set of values to define its' limits.

The question of the universality of human rights is repeatedly discussed, and in human rights documents, human rights, democracy, and rule of law are all claimed to be universally valid (United Nations 1948). Tolerance is related to Western liberal philosophy (Forst 2010; Heyd 2008; Williams 1996). However, the praxis of tolerance always occurs within a particular cultural and moral context. Even as we seek to develop conceptions of tolerance that are universal, cultural values are involved. Culture will influence the praxis of tolerance and its normative value in political life, as well as the different sets of values defining its limits. In this article I explore tolerance as a culturally dependent concept.

Sarah Song claims that 'Liberalism is not free of culture but expresses a distinctive culture of its own' (2014). Arguably, this distinct culture attached to the concept might be challenging when tolerance is to be acted out in diverging cultural contexts. Thus, there are two aspects of tolerance relevant here: the values defining its limits, and the value attached to the discourse of tolerance due to its role in democracy and the dominance of Western liberalism globally. Therefore culture counts in the understanding and praxis of tolerance.

Tolerance is a key concept in Western liberal philosophy and a foundation for the spread of human rights globally. Studying the global conditions for tolerance is important. States Melissa S. Williams:

There are other dimensions of the theory and practice of toleration that deserve scholarly attention. In particular, we are conscious of the non-Western traditions of toleration especially in Islam, Buddhism, and Confucianism, which it would have been revealing to juxtapose to the Western tradition represented here (Williams 2008, p. $\mathrm{x})$.

In my master thesis I conducted research in Japan on some Japanese individuals' interpretations of the first article of The United Nations Universal Declaration of Human Rights (Jørgensen 2010). The focus was on three central points: the Japanese informants' perception of human nature, their reaction to the first article of the Universal Declaration of Human Rights, and their reflections on the cultural legitimacy of human rights philosophy. In this article I will discuss the findings alongside theory to describe an alternative cultural context for tolerance to the Western liberal, and suggest some consequences for the understanding and praxis of tolerance in a Japanese setting. I will discuss in what ways the Japanese informants' relationship to the first article of the Universal Declaration of Human Rights may widen our understanding of the content and practice of tolerance in different cultural contexts.

My interviews support research that shows the influence of Confucian ethics on Japanese society; thus the relationship between liberal tolerance and Confucianism will be highlighted (Bellah 1985, 2003; Jørgensen 2010; Lebra 1976; Se and Karatsu 2004; Strand 2003, 2014; Yum 1997). 
My research question is:

On the basis of Japanese respondents' answers to questions about human rights philosophy, what seem to be central conditions for tolerance in Japan?

This is not a qualitative study of general conditions for tolerance in Japan, nor a comprehensive theory of the understanding of tolerance in a Japanese setting. My objective is to discuss the understanding and practice of tolerance in the light of empirical data from the interviews and knowledge on Japanese culture.

\section{'The East' and 'the West'}

This project is a comparative one. It compares Western liberal values with Japanese culture. Thus, it belongs to the school that dichotomizes 'the East' and 'the West'. When I speak of the East and the West, I simplify. By the East I mean the Japanese context I will describe in this article, which has parallels to Chinese, Korean, and other Confucian-influenced East Asian countries. By the West I mean the regions usually associated with liberal political philosophy, primarily Western Europe and North America.

In a comparative study like this, I will to a certain degree have to stereotype. Well aware of the similarities between Japanese and Western culture, in this article I focus more on the differences. Several Japanese scholars, like Yasuaki Onuma, Teruhisa Se and Rie Karatsu, discuss a 'Japanese conception of human rights', which indicates that they consider cultural differences relevant when dealing with human rights (Onuma 2000; Se and Karatsu 2004). The Japanese Liberal Democratic Party (LDP) is promoting revisions of the Constitution of Japan from 1947. In the pamphlet with Q\&As about the proposed revisions they state that:

rights are gradually formulated through the history, tradition and culture of each community. Therefore, we believe that the provisions concerning human rights should reflect the history, culture and tradition of Japan. (...) [T] he current Constitution includes some provisions based on the western theory of natural rights. We believe these provisions should be revised. (Repeta 2013, p.2 and 4) ${ }^{1}$

Culture is dynamic. Human interaction leads to negotiation of meaning, and culture is the product of interaction over time. People who interact and share life need a minimum of common conventions to be able to communicate and shape functioning communities. Norms, values and assumptions of reality are contributing to people's interpretations and directing perceptions and moral judgments (Geertz 1973, Strand 2014). This, of course, does not mean that people within 'a culture' are not diversified. Every society has internal cultural variations. However, people who interact more will share more of the same values; thus on an etic level ${ }^{2}$, we can discuss cultural differences.

First, I will deal with the concept of tolerance and discuss its link to Western liberalism and universalism. Next, I consider the relationship between human rights and tolerance. Then I will present my major findings before suggesting how some aspects of the Japanese context might have repercussions for the understanding and praxis of tolerance in Japanese society.

1The pamphlet is accessible on the LDP internet site in Japanese: https://www.jimin.jp/top.html 2Etic and emic perspectives are concepts often used in social anthropology. Emic meaning the perspective of persons within a culture, etic the observer or researchers' abstract description and analysis of a culture (Eriksen 2007, p. 49). 


\section{Tolerance}

Rainer Forst's work on the concept of tolerance is influential and illuminating (Forst 1997; 2010 ; 2012). According to Forst, tolerance can be explained by the components objection, acceptance, and rejection (Forst 2010, p.2). For a practice or a belief to be a candidate for toleration it must be objected to or disliked in the first place. Despite the objection there can be reasons for it to be accepted. But acceptance of objectionable beliefs and practices has its limits: some are rejected, not tolerated. The concept of tolerance does not have inherent criteria for the limits for toleration; it is in need of external norms that define what should or should not be tolerated. Therefore Forst calls toleration a 'normatively dependent concept' (Forst 2010).

According to Lawrence A. Alexander, "Demands for tolerance arise when people who interact hold conflicting views of right and wrong and good and bad" (2008, p.301). Alexander defines tolerance as "avoidance of conflictual engagement" (Alexander 2008, p.302). Therefore toleration is associated with forbearance. Tolerance is about enduring views or behaviour contrary to your own.

Tolerance is a political virtue, but it can also be seen as a moral attitude ${ }^{3}$ (Heyd 2008; Williams 1996). The two overlap: tolerance as a moral attitude influences political praxis and vice versa. ${ }^{4}$ This is not a survey of the Japanese political system, but of the cultural values relevant for the exercise of tolerance in Japan, in all areas of society. Williams and Waldron state:

Toleration, after all, is one of the defining topics of political philosophy - historically pivotal in the development of modern liberalism, (...) and central to our understanding of the idea of society in which individuals have the right to live their own lives by their own values (Williams and Waldron 2008, p.1).

Tolerance is accepting others' 'right to live their own lives by their own values'.

\section{Tolerance and Western liberalism}

Tolerance and liberalism are widely held to belong together (Brown 2008; Kymlicka 1995, p.154-155; Heyd 2008; Williams 1996; Williams and Waldron 2008). In the West, the political concept of tolerance has a complex history. I cannot provide a comprehensive presentation here, but only point to certain aspects central to the theme.

After more than thirty years of religious wars in Europe, the Peace of Westphalia in 1648 established the nation-state as a sovereign political entity. The authority to decide public religion became a matter of internal national affairs. This has highly influenced international law and the way to relate to nation-states ever since. However, there were religious minorities within the national borders, which led to clashes between Catholicism and Protestant Christianity. The liberal concept of tolerance developed as a way of dealing with the coexistence of conflicting views (Rawls 1999, p.424). As David Heyd writes, "The two contexts in which the modern idea of toleration gradually emerged were religion and royal grace" (Heyd 2008, p.172). According to Will Kymlicka, "The development of religious tolerance was one of the historical roots of liberalism" (Kymlicka 1995, p.155). Enlightenment philosophers like Locke, Bayle, Montesquieu, Voltaire, and Kant further

3 The relationship between the political concept of tolerance and tolerance as a moral attitude is complex. Please see Heyd and Williams for more thorough discussions (Heyd 2008; Williams 1996).

4 In the article 'Is Tolerance a Political Virtue?' Heyd claims that tolerance in a strict philosophic sense is not a political virtue. Still, he acknowledges that it is widely held to be (Heyd 2008). 
developed the concept, which became a central component of Western liberal democracy and human rights discourse (Bristow 2011; Forst 2010).

Tolerance developed in a context of strong contrasting beliefs and claims of absolute truth. Both Catholicism and Protestantism claim universal truth. This reminds us that tolerance is not the same as agreement but implies acceptance: it is possible to hold strong beliefs and claim the truth and still be tolerant. The quote associated with Voltaire, 'I deeply disagree with what you say, but will defend with my life your right to say it', underlines the same point. Tolerance does not demand harmony or consensus; it is a way of dealing with conflicting truths (Alexander 2008, p.302). This must be kept in mind as we study other cultural contexts.

Tolerance is neutral in the sense that it requires external norms to define its limits (Forst 2010). Still, tolerance has a distinct role and position in society. There seems to be a hegemonic discourse connected to tolerance that is linked to Western liberal values. Today tolerance, at least in the West where the liberal conception is influential, is valued as a positive and necessary element in political, personal, and interreligious encounters (Rawls 1999, p.591; Williams and Waldron 2008). Therefore it is not neutral: respect for diversity and refraining from conflictual engagement is valued and encouraged within certain limits. This shows that the concept of tolerance contains value. If we are not tolerant towards divergent political or religious views, we might meet rejection.

David Heyd states:

Unlike the concepts of the good or the just, toleration has a relatively short history and one that is mostly confined to one civilization. Being a 'thick' concept, it is much more dependent on particular normative and cultural circumstances than its universal moral cognates (Heyd 2008, p.173). ${ }^{5}$

Modernity and Western philosophy, democracy, and human rights have spread globally through Western dominance. Through its roots in liberal philosophy, tolerance is connected to individualism, autonomy, and freedom - freedom of speech, conviction, and religion, to mention a few (Williams and Waldron 2008). All these forms of freedom demand tolerance, which is relevant to my examination of the concept of tolerance from a Japanese Confucian perspective and will thus be highlighted in this article. Still, it is important to recall (even if this is obvious) that being tolerant is not an exclusively Western praxis. The Western liberal tradition did not invent the moral attitude of tolerance. But liberal tolerance as a political virtue is, according to Heyd, "mostly confined to Western civilization" (Heyd 2008, p.173).

So two sides of the concept might be culturally dependent:

1. The place and value of toleration in political life; its discursive role.

2. The divergent cultural norms that impose the limits of tolerance.

\section{Tolerance as a universal concept}

The claim that tolerance is a culturally dependent concept might seem obvious. Culture counts when we deal with tolerance. However, in human rights documents, and according to many political philosophers, human rights, democracy, and rule of law are universally valid (Donnelly 1999; Habermas 2012; United Nations 1948). When we seek to develop conceptions of tolerance that are universal, they will in one way or another involve culturally defined values, and can therefore be contested.

5 'Thick description' is a term coined by Clifford Geertz and refers to describing cultural phenomena in a detailed way including interpretation and meaning (Geertz 1973). 
Forst discusses the justification for toleration and argues:

One must be willing to argue for basic norms that are to be reciprocally and generally valid and binding with reasons that are not based on contested 'higher' truths or on conceptions of the good which can reasonably be questioned and rejected (Forst 2010, p.10) ${ }^{6}$

Legitimation of tolerance based on reciprocally and generally valid conceptions of the good based on reason is an attractive goal. But notions of what is reasonable are not always shared. What is reasonable is determined by axioms or basic values, and these are culturally dependent. Claims of universality are also made by Jürgen Habermas through what he calls discourse morality. Put simply, he supports the global adoption of human rights and democracy on the basis that the ruling global discourse carries inherent logical claims that demand democracy and human rights (Habermas 2012). In the words of Robert Brandom (1994, p.599), "Objectivity appears as a feature of the structure of discursive intersubjectivity". The universality and objectivity of human rights is a result of sharing the same global discourse.

\section{Human Rights and tolerance}

Tolerance is a vital part of Western political philosophy and has a central position in human rights discourses, particularly concerning civil rights. Tolerance and human rights are part of the same Western political and ideological development. Tolerance is a precondition for human rights and democracy. Human rights and tolerance rest on the same foundation of human dignity and respect for freedom of speech, conscience, and religion. Tolerance is vital to the health of pluralistic, democratic societies with conflicting truths, convictions, and choices, which human rights seek to secure (United Nations 1948).

The first article of The United Nations' Universal Declaration of Human Rights (UDHR) states: "All human beings are born free and equal in dignity and rights. They are endowed with reason and conscience and should act towards one another in the spirit of brotherhood" (United Nations 1948). The claim that we are born free and equal in dignity and rights is a foundation for tolerance; we are free to make autonomous choices, thus tolerance is needed to tolerate that other people make choices contrary to our own. ${ }^{7}$ In this way, tolerance is the other side of the coin of rights. If we have rights, they are worthless if fellow citizens or the state do not tolerate that anyone pursue them. If we do not tolerate other people living out their rights, the rights have no practical meaning. In the liberal context, if you are not free to choose your leaders, speak your opinions, and exercise your religion, your dignity as an individual is limited. Thus, freedom and tolerance are key concepts in the human rights discourse. Although this is a basis for human rights philosophy and claimed to be universal, individual freedom and tolerance are contested in different parts of the world.

However, the human rights discourse is also related to tolerance in that it can serve as a possible global set of norms that can give tolerance its limits. Human rights have gained high global status and authority and might be the closest we have to common universal norms at the present point.

6 For a thorough discussion of Forst's term 'the right to justification', see Forst, Rainer (1997): Foundations of a Theory of Multicultural Justice. Constellations. Volume 4. No. 1. 1997. Blackwell Publishers. UK and USA; and Forst (2010): Two stories about toleration. Recon Online Working Paper 2010/15, August 2010. (http://econpapers.repec.org/paper/erpreconx/p0071.htm)

7 The Preamble of The Universal Declaration of Human Rights states: "Whereas recognition of the inherent dignity and of the equal and inalienable rights of all members of the human family is the foundation of freedom, justice and peace in the world ..." (United Nations 1948). 
So, tolerance and human rights relate in at least two ways: human rights require the concept of tolerance to have practical meaning, and human rights discourse is a potential deliverer of common norms to define the limits of the (potentially) global praxis of tolerance.

\section{The Japanese context}

Japanese culture and society is often seen as a striking mixture of continuity and change. Isolation from the rest of the world from 1600 to the mid-nineteenth century, along with a uniquely homogenous population ( $98.5 \%$ ethnic Japanese), has left Japan with a distinct culture. In 1854, the Americans sailed into Tokyo Bay and forced the isolation to end. Japan responded to this with an attitude of 'if you can't beat them, join them'. The Meiji Restoration was a turning point in Japanese history and marked the end of the feudal samurai era and military rule (Kalland 2005). This was followed by appropriation of Western philosophy and technology. Combined with the rich cultural, social, and economic development and structural preconditions, like the high literacy rate and high general level of education, Japan became a dominant power in East Asia, which its military history in the following decades clearly revealed (Bellah 2003; Kalland 2005). After their loss in World War 2 , the United States imposed the new constitution of 1947 . Recent research reveals more Japanese influence on the constitution, still the American dominant position remains strongly supported, and the constitution was marked by Western liberal and human rights principles (The Constitution of Japan 1947, Parisi 2002). In the post-war era, Japan has participated in the global economy and culture, with the result that the country reflects a complex mix of traditional culture and global influence.

Japan has a constitution and a political system well suited to liberal principles. Freedom House's annual report for 2014 on the status of the nations of the world in regard to civil and political rights ranks Japan among the world's top nations, awarding it the status Free with a score of 1 , where 1 is the most and 7 the least (Freedom House 2014). Its constitution and political institutions seem to secure liberal toleration in a way similar to the West.

Japan's post-war constitution underscores human rights and liberal freedom:

Article 97. The fundamental human rights by this Constitution guaranteed to the people of Japan are fruits of the age-old struggle of man to be free; they have survived the many exacting tests for durability and are conferred upon this and future generations in trust, to be held for all time inviolate.

Article 11. The people shall not be prevented from enjoying any of the fundamental human rights. These fundamental human rights guaranteed to the people by this Constitution shall be conferred upon the people of this and future generations as eternal and inviolate rights.

(The Constitution of Japan 1947) 
The two dominant religions in Japan are Shintoism and Buddhism. Eastern religion is less doctrinal and absolute and seemingly more tolerant than in the West (Reader 1994; Strand 2003). A Japanese person might be affiliated with more than one religion ${ }^{8}$ : they might bless their children in Shinto shrines, marry in a Christian chapel, and be buried as Buddhists (Japan Statistical Yearbook 2014). They are said to be 'practically religious' (Reader 1994). The native Japanese religion, Shinto ('the way of the gods'), does not have holy scriptures and does not demand a specific way of conduct or give clear moral guidelines. It is a way of living in harmony with and relating to nature, kami, and the ancestors (Lande 1990; Strand 2003).

Confucianism came to Japan in the mid-sixth century and has to various degrees influenced Japanese culture since. It is a philosophy for harmony and stability, with little religious content. The 'five basic relationships', namely between father and son, ruler and subordinate, man and wife, older and younger brother, and friend and friend, are all regulated by ri, right ritual, or correct behaviour and social regulations. According to Madsen:

within the Confucian tradition, rituals referred to much more than the ceremonies marking major life-cycle events or communal occasions. Rituals also included what we would call rules of etiquette, and in traditional Asian cultures, such rules were densely woven throughout the whole fabric of ordinary life (Madsen 2007, p.121).

The relationships are hierarchical, which means that hierarchy is part of the 'harmonious order'. Rulers who are morally developed will take care of their subordinates the way a father cares for a son (Lebra 1976).

Takie Sugiyama Lebra describes Japanese culture as dominated by social relativism. Social relativism is a combination of 'social preoccupation' and 'interactional relativism' (Lebra 1976). Accordingly, Japanese emphasize 'proper-place-occupation' and orient themselves towards the group for moral guidelines with little need of abstract or general principles (Lebra 1976). Se and Karatsu refer to Lebra when they describe the Japanese as possessing an 'inter-dependent construal of self' in contrast to the Western 'independent construal of self' (Lebra 1976; Se and Karatsu 2004): "a person with an inter-dependent construal of the self tends to regard morality primarily as keeping good terms with others or fulfilling social roles smoothly" (Se and Karatsu 2004, p.275). However, Japan is changing. Traditional gender roles and hierarchical order are being challenged, although the older values are still influential (Takenaka 2011).

\section{Transcendent principles and social relativism}

Tolerance and ethics belong together. A commonly perceived difference between the East and the West concerns the development of law and moral principles (Onuma 2000; Madsen 2007; Se and Karatsu 2004). The West has been strongly influenced by Christianity (Forst 2010; Habermas 2006, p.151; Heyd 2008). Most schools were started by the church and centred on the Bible, and priests were public educators. Following the Enlightenment, God's position and authority declined within the public sphere. Still, the belief in a prime mover has left traces and influences the way people relate to laws and moral principles (Madsen 2007). Despite the more recent postmodern turn (Henriksen 2005; Strand 2014), the West is oriented towards abstract universal principles. Japan is more based on social relativism (Lebra 1976). Described in broad strokes, the Japanese do not look to abstract principles,

8 In average every Japanese person is affiliated with 1,55 religions. Based on figures from 2011, Japan Statistical Yearbook 2014 http://www.stat.go.jp/english/data/nenkan/1431-23.htm. 
but practice situational ethics derived from the group and the social setting (Dancy 2013; Lebra 1976; Madsen 2007; Onuma 2000; Se and Karatsu 2004): Madsen argues:

Much of Western moral philosophy seems to seek a set of abstract principles whether based in a revelation of the will of God or in principles of Reason itself - that transcend any particular context. Then it uses a kind of casuistry to apply these principles to particular situations. In the Confucian perspective, however, moral principles are not derived from abstract ideas but from the concrete rituals of ordinary life (Madsen 2007, p.123).

Se and Karatsu underlines the same points and state:

It is a situation based morality: a moral view that places stress not on abstract moral principles, but on matters embedded in the surrounding situation such as concrete social relationships, the feelings of others, and social roles (Se and Karatsu 2004, p.274).

To put it simply: in Japan you do not look up to find the truth, you look around. You do not look for universally valid, abstract principles; you tend to consider your webs of relationships to find the right thing to do in a given situation.

Individual autonomy has different conditions when truth is derived from the group and actual situations rather than from universal abstract principles. An individual is freer to act according to steady, general principles than when beholden to a group. On this basis, it is tempting to say that when 'transcendent' principles are lacking, stronger interpersonal bonds are required. We might label it government by law versus government by group. Transcendent principles and legalism are therefore a precondition for individual autonomy. This of course impacts the relationship to human rights and tolerance. Less freedom to diverge from the group and stronger social obligations imply less tolerance for divergence.

\section{Methodology}

The interviews were conducted in Japan during the summer and fall of 2009. I interviewed twelve Japanese scholars: university professors, lawyers, police officers, and a religious leader. Due to the lack of gender balance in these positions in Japan, only two were women. Therefore possible gender differences have not been a focus. I chose to interview scholars because of the philosophic focus of the project. They were expected to have the knowledge and intellectual tools to engage this topic. This might impact the findings.

The interviews were semi-structured with emphasis on a relaxed and informal atmosphere, and their format was more of an informal discussion than formal questions and answers. I conducted qualitative interviews one to one with the informants, except for an interview with a group of five police officers and lawyers. In the group interview we all sat around a table conversing together. The superior did most of the talking, but each participant made unique contributions. All the interviewees were provided with a written introduction in Japanese that contained the first article of the Universal Declaration of Human Rights and described the focus of the research. It also informed them of the preservation of anonymity, the right to withdraw at any stage of the research process, and due policy for storage of the recordings of the interviews. ${ }^{9}$ They all agreed to let me record the interviews, which made it possible for me to go back and study the interviews in detail. Liability and reliability were

9 The research was conducted according to the ethical guidelines of The Norwegian National Committees for Research Ethics in the Social Sciences and the Humanities (NESH) (2006) and approved by the Norwegian Social Science Data Service (NSD) (2014). 
ensured through standard procedures, but the generalizability is limited, as is usually the case with in-depth interviews.

The Japanese often value politeness to show respect. Aware that this tendency might affect my respondents' answers, I tried to ensure an environment that would encourage them to speak the honne and not the tatemae (truth and façade, respectively). As I speak Japanese quite well, the interviews were conducted in Japanese, but with assistance from English when needed.

\section{Tolerance - The Japanese way?}

The article began with the claim that tolerance is practiced everywhere. But is toleration in Japan the same as toleration in the West? As we have seen, Japan has a constitution and a political system enshrining liberal principles. Its constitution and political institutions seem to secure liberal toleration in a way similar to the West.

The interviews generated some significant findings:

- All the informants considered the first article of the Universal Declaration of Human Rights as reflecting Western thought

- The notion that humans are 'born with' rights was perceived as foreign to Japanese culture and conceptions of human nature

- All the informants acknowledged human rights to be good and important, although not the only possible expression of 'the good'

- Many expressed the opinion that support for human rights is obvious for the Japanese

My research showed differences in the perception of human nature, the conditions for freedom and autonomy, and the justification for human rights. I will argue that the findings all point to and show different sides of the inter-dependency that I claim to be a main feature of Japanese culture. The findings will be grouped under three subheadings: Perception of human nature, freedom and autonomy, and particularism and universalism.

\section{Perception of human nature}

Culture shapes the way human rights are perceived locally. Which rights we bestow on people depends on how we see human beings (Matlary 2007, p.180; Se and Karatsu 2004, p.272). A core value in human rights philosophy is the inherent dignity of a person just by virtue of being human. We are 'born free' and 'born with' dignity and rights. As we have seen, the first article of the Universal Declaration of Human Rights anchors those rights in human nature.

Therefore the first focus of the interviews concerned perceptions of human nature. We discussed the question, what is a human being? Some responses are quoted below:

According to Confucian thought, we are not born alike. If you are born poor, don't complain! It is not like we are all the same in the eyes of God. The reaction when this philosophy was first introduced in Japan was probably, 'Eh?'! 
These statements suggest unfamiliarity with the claim that we are 'born with' rights. They also provide information on attitudes towards hierarchy: "We are not born alike." Hierarchy limits autonomy and thus tolerance of divergent behaviour. The informant uses the word 'introduced', indicating that he considers the thought 'being born alike' to have been presented to the Japanese from outside. But he also says, 'According to Confucian thought', which reflects not necessarily his own views but his assumptions about the Japanese culture.

The belief that we are not born alike and 'the same in the eyes of God' affects the justification for equal rights. According to another informant, an individual's rights are not necessarily inherent. He said that the sentiment "Get rid of those individuals outside the group that don't behave well!" would, according to traditional Japanese thought, be a common reaction to people unwilling to cooperate.

One side of the Japanese culture-specific view of human nature is the emphasis on living in harmony with nature (Lande 1990; Strand 2003; 2014). This is expressed by one of my informants in the statement 'We respect all nature. In Japan, the whole nature is divine. Human beings do not have a sovereign position. We respect the whole nature. We respect many gods'. Nature, human beings, gods, and ancestral spirits are believed to be interdependent (Lande 1990; Strand 2003).

The Japanese emphasize living as part of and in harmony with nature. Still, nature is not considered 'holy' in the sense that humans cannot and should not touch it or shape it. Bonsai trees and Japanese gardens are practical examples of how the Japanese value shaping nature to perfect it. The same goes with human beings. Education is highly valued in Confucianism (Kalland 2005; Tucker 2012). Cultivation and learning is vital to the process of developing humanness. One of the informants put it quite strongly: "You are not human until you have been educated. You are homo sapiens, of course, but you must be cultivated." In the interview with the group of police officers and lawyers the same tendency to focus on cultivation as necessary to reach full personhood dominated. When I asked what a human being is I expected relatively straightforward answers, but the response often involved a description of child rearing or cultivation.

In Japan, your identity, personhood, and maturity are strongly connected to your social setting. This is very much in keeping with the Confucian influence on Japanese society. By learning the social codes and finding your proper place and role, you mature and gain personhood: Wm. Theodor DeBary and Lebra underline the same points:

Here personalism expresses the worth and dignity of the person, not as a raw, 'rugged' individual, but as a self shaped and formed in the context of a given cultural tradition, its own social community, and its natural environment to reach full personhood (DeBary 1998, p.25).

For the Japanese, empathy ('omoiyari' in Japanese) ranks high among the virtues considered indispensable for one to be really human, morally mature, and deserving of respect (Lebra 1976, p.38).

Inter-dependency seems to require learning the social codes, proper-place-occupation, and cultivation (Lebra 1976; Madsen 2007; Se and Karatsu 2004). Another informant stated: "We are free within our context. We are free when we have learnt the rules." Human dignity seems to be more dependent on cultivation and 'learning the rules' than inherent. 


\section{Freedom and autonomy}

As I have argued, tolerance is related to freedom and autonomy. Williams and Waldron define tolerance as "central to our understanding of the idea of society in which individuals have the right to live their own lives by their own values" (Williams and Waldron 2008, p.1).

Freedom is a core ingredient in the liberal conception of tolerance, so I will shed some light on what my research indicates when it comes to the Japanese informants' response to the claim that we are 'born free'. It can be expected that more 'inter-dependency' will result in less personal freedom, which will imply less acceptance or tolerance of divergent views. Stronger emphasis on doing the right thing for the actual situation creates a different context for tolerance. One of the informants stated: "There is a difference between social and psychological freedom." This indicates that the informant holds that social freedom is limited but there is room for personal autonomy, which she calls 'psychological freedom'. Another stated: "We are free from neighbourhood ties, and free from feudalism. From $70 \%$ bound to $30 \%$ bound. We are not free in work situations."

In the Japanese setting, claiming one's rights is often perceived as immature (Madsen 2007). This is related to inter-dependency (Madsen 2007), which lessens room for and tolerance of divergence. Freedom of autonomous conduct is highly valued in the West. In Japan the same is often considered immature and selfish, lacking in sensitivity to others and social responsibility (Madsen 2007, p.129; Se and Karatsu 2004). Madsen outlines Confucian thought in this way:

By themselves, laws that protect individual rights encourage people to act in selfish ways, and by themselves such laws cannot generate the sense of social responsibility necessary to bring people into right relationship (Madsen 2007, p.129).

The quote below is an e-mail I received as a response to a request to interview two of my contact's female staff members. It is loaded with possible meanings.

Dear Trond-sama,

My staff acknowledged receiving your interview yesterday. However, at my request, in your interview with my staff, do not record their voice, please. In general, it is thought that a typical Japanese woman has a tendency not to express her opinion. In that sense, my staff are not such kind of women, but women who consider and work in the Western manner. They may have steady principle and insistence, and may have acknowledged receiving the interview. On the other hand, they may have an idea that I am their boss, and it is not possible to refuse it even a little. I am worrying about it.

Therefore I consider that you'd better interview without recording them.

\section{Best Regards}

It seems clear that my contact thinks that there are differences between 'the Western manner' and the Japanese manner. That is interesting in itself. The emphasis on hierarchy and the gender roles revealed here also point to aspects of inter-dependency. The statement "it is thought that a typical Japanese woman has a tendency not to express her opinion", says a lot, both concerning gender roles and inter-dependency. The e-mail also suggests something about the way the Japanese commonly relate to superiors: "I am their boss, and it is not possible to refuse it even a little." "We are not free in work situations" (from a previous quote) indicates that work life might be an area of society where 
traditional values and hierarchy are particularly strong. The phrase "I am worrying about it" indicates a caring attitude, which can be interpreted as a sign of the Confucian value of the superior assuming a paternal role towards his subordinates (Madsen 2007, p.128). The quote "we are free within our context. We are free when we have learnt the rules" points to the importance of context and suggests that it is possible to be free when you have learned the rules that apply for that context. There seems to be a context of hierarchy and gender roles revealed in this e-mail that limits individual freedom and autonomy. There might be freedom within the context, but adjusting to the context might still limit autonomy. Arguably, having to adjust to relationships and proper-place-occupation limits autonomy and free expression and thus tolerance.

Tolerance and rights are connected in such a way that in the context of hierarchy, the person in the superior position will have stronger rights than the subordinate. Less will be tolerated from the latter than from the former. One informant said (humorously): "In Japan people would probably have waited for the superiors to say: Come on! Let's follow human rights!" Madsen underlines the same point by suggesting that a Confucian approach to human rights might be to "try to cultivate a moral elite that could persuade others to improve themselves by following the virtues of the superior person" (Madsen 2007, p.214).

But we need to remember that all cultures have rules and social expectations that limit autonomy. Nevertheless, there seems to be an opinion among the informants that social limitations in Japan differ from 'the Western manner' and that the Western manner is freer.

Taken together, these statements illustrate a Japanese perception of human nature that points to inter-dependency, which is likely to limit autonomy. There might be traces of Confucian inter-dependency surfacing, creating a different context for tolerance.

\section{Universalism and particularism}

It seemed that the informants found justification for human rights to be more dependent on specific situations and relationships than based in human nature (that is, based on particularistic morality). All of the informants held the first article of the Universal Declaration of Human Rights to be reflective of Western thought. One informant said: "The rights are not a source flowing from human nature; they come more and more for instance from the constitution. We used to get our rights from the emperor. It must be cultivated, it is not from birth." We discussed the Japanese tendency to look 'around' to find the truth in contrast to the Western tendency to look 'up'. According to this informant, people derive their rights from the emperor or the constitution or the social setting and hierarchy, and not from birth or abstract universal principles. The statement "In Japan people would probably have waited for the superiors to say: Come on! Let's follow human rights!" similarly supports inter-dependency. The truth or the right thing to do is derived from superiors. Correct and good behaviour and deeds seem to be based pragmatically on particularistic morality. Viewing human nature or personhood as being more inter-dependent influences the moral justification for autonomy, and thus for tolerance.

Orientation towards abstract moral principles is held to be a feature of Western culture (Madsen 2007; Se and Karatsu 2004). If we hold that Christianity and the belief in a prime mover are sources for universal and general principles, the statement "We respect many Gods" is interesting. Transcendent principles might lead to objective, general rules that make it easier to act in autonomous ways. In contrast, Japanese inter-dependency might produce values that are more inter-subjective and relation- and situation- dependent. Particularism and inter-dependency belong together. Human beings' superior position in creation or nature might be a basis for Western individualism, in contrast to the belief that 
"human beings do not have a sovereign position", a statement from the same informant. This does not necessarily imply a limit for tolerance, but a different context for it.

\section{Some possible implications of the Japanese environment for tolerance}

Freedom and duty are often viewed as contradictory. But can the Japanese environment suggest a form of tolerance based on duty instead of freedom and autonomy? Social relativism, inter-dependency, and the Confucian value of 'proper-place-occupation' demand a strong sense of duty. Following the prescribed course of action for a given situation implies duty. Are people less tolerant when they sacrifice their own desires in order to save others from losing face than when they claim their right to be tolerated for having their own way? The answer, of course, depends on how we define tolerance and the morally good.

Tolerance as "avoiding conflictual engagement" (Alexander 2008) is exercised in Japan through the obligation to follow the right course of action (ri) (Madsen 2007). Adjusting to one's proper role and place in social relationships requires much tolerance. But this is a different kind of toleration, one that pays less attention to the value of individualist freedom and autonomy. Can a different kind of tolerance be tolerated, or is it possible to argue for the universality of the liberal values of autonomy and individualistic freedom as a basis for tolerance? And how does this relate to human dignity?

The first article of the Universal Declaration of Human Rights compels us to act in 'the spirit of brotherhood'. Japanese inter-dependency and 'other-consciousness' might involve a stronger sense of brotherhood than in the individualized West. Brotherhood might limit freedom, but does brotherhood limit tolerance? Rainer Forst states, "The politically free, the personally autonomous and the ethical good life may be three separate things" (Forst 2010, p.9). Is the duty to follow the morally good a higher good than freedom? If not, how much do we need liberal tolerance? This question might arouse instinctive protests; the freedom that liberal tolerance secures is highly valued in the dominant Western political discourse. Exploitation and misuse of superior status in hierarchy due to the duty to adjust to one's 'proper place' might meet rejection. Therefore the evaluative role of tolerance surfaces again and indicates that the concept is not neutral. Values and normative aspects are strongly connected to tolerance, implying that different cultural values do count. Tolerance is a culturally dependent concept, I will argue.

\section{Concluding remarks}

My findings appear to fit many common stereotypes of the East vs. the West. Some of these stereotypes seem to be confirmed by the informants and supported by theory. But as I have underlined, the comparative perspective of this article has also revealed departures from stereotype. Some of my informants insisted that "the Japanese support human rights!" in a way that suggested that this is an obvious fact. The greatest differences surfaced when dealing with cultural 'roots'. The findings might emphasize traditional Japanese thought at the expense of my informants' personal opinions or contemporary views. Part of our discussions involved looking back to possible cultural sources for human rights.

I have asked whether the Japanese environment has shaped a different kind of tolerance based on duty. Must tolerance be morally motivated by respect for autonomy or can a motivation for tolerance based on brotherhood, other-consciousness, and duty be equally relevant and thus expand the justification of - and our universal understanding of the values and limits of toleration as praxis? 


\section{References}

Alexander, Lawrence (2008). Is there logical space for toleration on the Moral Map for Toleration? In Williams M. and Waldron J. (Ed.). Toleration and its Limits. New York University Press: New York.

Angle, Stephen C. (2002). Human Rights and Chinese Thought - A Cross-Cultural Inquiry. Cambridge University Press: Cambridge UK. http://dx.doi.org/10.1017/CB09780511499227

Bellah, Robert N. (1985). Tokugawa Religion - The Cultural Roots of Modern Japan. The Free Press: New York.

Bellah, Robert N. (2003). Imagining Japan - The Japanese Tradition and its Modern Interpretation. University of California Press: Los Angeles.

Brandom, Robert (1994). Making it Explicit: Reasoning, Representing, and Discursive Commitment. Harvard University Press: Cambridge.

Bristow, William, "Enlightenment", The Stanford Encyclopedia of Philosophy (Summer 2011 Edition), Edward N. Zalta (ed.) http://plato.stanford.edu/archives/sum2011/entries/enlightenment

Brown, Wendy (2008). Tolerance as/ in Civilizational Discourse. In Williams M. and Waldron J. (Ed.). Toleration and its Limits. New York University Press: New York.

Dancy, Jonathan, "Moral Particularism", The Stanford Encyclopedia of Philosophy (Fall 2013 Edition), Edward N. Zalta (ed.) http://plato.stanford.edu/archives/fall2013/entries/moral-particularism

DeBary, Wm. Theodor (1998). Asian Values and Human Rights - A Confucian communitarian perspective. Harvard University Press: Cambridge MA.

Eriksen, Thomas Hylland (2007). Små steder, store spørsmal - Innføring $i$ sosialantropologi. Universitetsforlaget: Oslo.

Forst, Rainer (1997). Foundations of a Theory of Multicultural Justice. Constellations. Volume 4. No. 1. 1997. Blackwell Publishers: UK and USA

http://dx.doi.org/10.1111/1467-8675.00037

Forst, Rainer (2008). Toleration and Truth: Comments on Steven D. Smith. In Williams M. and Waldron J. (Ed.). Toleration and its Limits. New York University Press: New York.

Forst, Rainer (2010). Two stories about toleration. Recon Online Working Paper 2010/15, August 2010.

http://www.reconproject.eu/projectweb/portalproject/AbstractRECONwp1015.html

Forst, Rainer (2012), "Toleration", The Stanford Encyclopedia of Philosophy (Summer 2012 Edition), Edward N. Zalta (ed.)

http://plato.stanford.edu/archives/sum2012/entries/toleration

Freedom House (2014).

http://www.freedomhouse.org/report-types/freedom-world\#.U38r3WyKDcs

Geertz, Clifford (1973). The Interpretation of Culture. Basic Books: New York.

Habermas, Jürgen (2006). Time of Transitions. Polity Press: Cambridge.

Habermas, Jürgen (2012). Legitimering på grunnlag av menneskerettigheter.

Agora 2012/ 1.

http://www.idunn.no/ts/agora/2012/01/legitimering menneskerettigheter

Hatfield, Gary, "René Descartes", The Stanford Encyclopedia of Philosophy (Summer 2014 Edition), Edward N. Zalta (ed.)

http://plato.stanford.edu/archives/sum2014/entries/descartes 
Henriksen, Jan-Olav and Pål Repstad (2005). Tro i Sør - Sosiologiske og teologiske blikk på sørlandsk religion (Faith in the South: Sociological and Theological Views on Religion in Southern Norway.) Fagbokforlaget: Bergen

Heyd, David (2008). Is Toleration a Political Virtue? In Williams M. and Waldron J. (Ed.) Toleration and its Limits. New York University Press: New York.

Japan Statistical Yearbook 2014. http://www.stat.go.jp/english/data/nenkan/1431-23.htm (Read 12.10.2014)

Jørgensen, Trond (2010). Menneskerettighetenes filosofiske fundament i møte med japansk kultur og verdensbilde. (The Philosophical Foundation of Human Rights meeting Japanese Culture and Worldview). Masteravhandling i Global Studies. Misjonshøyskolen: Stavanger.

Kalland, A (1996). Japan, i: Howell, Signe og Melhus, Marit (red.) Fjern og nær Sosialantropologiske perspektiver på verdens samfunn og kulturer. Ad Notam Gyldendal: Oslo.

Kalland, Arne (2005). Japans Historie. Cappelen: Oslo.

Kymlicka, Will (1995). Multicultural Citizenship - A Liberal Theory of Minority Rights. Oxford University Press: Oxford UK.

Lande, Aasulv (1990). Japans religionar. Det Norske Samlaget: Oslo.

Lebra, Takie Sugiyama (1976). Japanese Patterns of Behavior. University of Hawaii Press: Hawaii.

Matlary, Janne Haaland (2007). When Might Becomes Human Right - Essays on Democracy and the Crisis of Rationality. Gracewing: Herefordshire.

Norwegian Social Science Data Service (NSD) (2014). http://www.nsd.uib.no/nsd/english/pvo.html

Onuma, Yasuaki (2000). In Quest of Intercivilizational Human Rights: Universal vs. Relative Human Rights Viewed from an Asian Perspective. Asia Pacific Journal of Human Rights and the Law, Vol. 1, Nr. 1. (

http://dx.doi.org/10.1163/15718150020954741

Parisi, Lynn (2002). Lessons on the Japanese Constitution. http://spice.stanford.edu/docs/131

Rawls, John (1999). Collected Papers. Harvard University Press: Cambridge, Massachusetts, London

Reader, Ian and George J. Tanabe, Jr. (1998). Practically Religious: Worldly Benefits and the Common Religion of Japan. University of Hawaii Press: Honolulu.

Rebick, M. og Takenaka, A. (ed.) (2006) The Changing Japanese Family. Routledge: London and New York.

Repeta, Lawrence (2013). Japan's Democracy at Risk - The LDP's Ten Most Dangerous Proposals for Constitutional Change. The Asia-Pacific Journal, Vol. 11, Issue 28, No. 3, July 15, 2013.

Se, Teruhisa and Karatsu, Rie (2004). A conception of human rights based on Japanese culture: Promoting cross-cultural debates. Journal of Human rights, Vol. 3, Nr. 3. http://dx.doi.org/10.1080/1475483042000224842

Song, Sarah, "Multiculturalism", The Stanford Encyclopedia of Philosophy (Spring 2014 Edition), Edward N. Zalta (ed.)

http://plato.stanford.edu/archives/spr2014/entries/multiculturalism

Strand, Svein Erik (2003): Perceptions of the Afterlife Among Some Japanese Evangelicals: A Study of Contrasting Worldwiews. Trinity International University: Deerfield, Illinois. 
Strand, Svein (2014). Transcendence Descended - Limiting God to the Immanent Sphere. Mission Studies 31 (2014) 44-59. Brill: Leiden.

http://dx.doi.org/10.1163/15733831-12341308

The Constitution of Japan (1947).

http://japan.kantei.go.jp/constitution and government of japan/constitution e.html

The Norwegian National Committees for Research Ethics in the Social Sciences and the Humanities (NESH) (2006). Guidelines for research ethics in the Social Sciences, law and the Humanities. https://www.etikkom.no/globalassets/documents.pdf

Tucker, John (2012), "Japanese Confucian Philosophy", The Stanford Encyclopedia of Philosophy (Winter 2012 Edition), Edward N. Zalta (ed.)

http://plato.stanford.edu/archives/win2012/entries/japanese-confucian

United Nations (1948). The Universal Declaration of Human Rights. http://www.un.org/en/documents/udhr/

Williams, Bernard (1996). Toleration, a Political or Moral Question? Diogenes December 1996 44: 35-48.

http://dx.doi.org/10.1177/039219219604417606

Williams, Melissa S. and Waldron, Jeremy (Ed.) (2008). Toleration and its Limits. New York University Press: New York.

Yum, June Ock (1997) The Impact of Confucianism on Interpersonal Relationships and Communication Patterns in East Asia. I: Samovar, Larry A \& Richard E. Porter. Intercultural Communiction - A reader. Wadsworth: Belmont, California.

http://dx.doi.org/10.1080/03637758809376178 